\title{
Effects of Forest on Mean Annual Runoff in North China
}

\author{
Henian Wang ${ }^{1,2}$, Weigang Xu ${ }^{1,2 *}$, Manyin Zhang ${ }^{1,2}$, Lijuan Cui ${ }^{1,2}$, Xinxiao Yu ${ }^{3}$ \\ ${ }^{1}$ Institute of Wetland Research, Chinese Academy of Forestry, 100091, Beijing, China \\ ${ }^{2}$ Beijing Key Laboratory of Wetland Services and Restoration, 100091, Beijing, China \\ ${ }^{3}$ Beijing Forestry University, 100083, Beijing, China
}

Received: 11 May 2017

Accepted: 23 July 2017

\begin{abstract}
The forest-water relationship is a hot and important issue in ecohydrology studies. China has implemented many large-scale reforestation programs in the past decades to address growing soil erosion and desertification, but that also caused serious water yield reductions. In this study, based on the simple water balance equation, we made statistical and graphic analyses on the long-term hydrological data of the 42 watersheds in the rocky mountain area of northern China, and then we were able to analyze the impact trend of forest on water yield. Our results show that the impact of forest on runoff is very weak in the lower-precipitation regions (in this study $<500 \mathrm{~mm}$ ). In the higher-precipitation regions $(>500 \mathrm{~mm})$ the impact of forest on reducing water yield is different with the increasing forest coverage $(f)$, and runoff shows an impact trend of "weak-big-severe"; the largest absolute MAR is about $225 \mathrm{~mm}$, and the largest MAR ratio is about $35 \%$. We highlight the importance of dividing different forest-coverage phases in analyzing the effect of a forest on water yield.
\end{abstract}

Keywords: forest, runoff, effects, northern China

\section{Introduction}

With the worsening of the environment and growing awareness of the ecological benefits of forests, many countries or regions are actively conducting reforestation efforts to increase forest coverage. To address growing soil erosion and desertification, China has implemented many large-scale reforestation programs in recent decades, with total investment reaching $¥ 720$ billion (\$114 billion US) [1]. However, reforestation could also potentially reduce water capacity [2-6]. Because of this,

*e-mail: submission2013@126.com correct understanding of the forest-water relationship is particularly important.

There have been many influential studies about understanding forest and water relationships during the past century around the globe. Farley et al. (2005) compiled datasets of watersheds located in various geographic regions around the world, and discussed the effects of afforestation on water yield [7]. Peel et al. (2010) analyzed the vegetation impact on mean annual evapotranspiration at a global catchment scale [8]. Beck et al. (2013) studied the regional annual water yield from forest lands and its response to forest regeneration in 12 meso-scale humid tropical catchments [9]. Yao et al. (2012) synthesized previous studies, and discussed the effects of forest recovery on summer streamflow [10]. 
Although researchers concur that forests decrease water yield, the extent of decrease differs. Farley et al. (2005) made a global analysis using 26 catchment datasets and 504 observations and found the annual water yield was reduced by 44 and $31 \%$ when grasslands and shrublands, respectively, were afforested [7]. Sun et al. (2006) examined the sensitivity of water yield responding to forestation across China, then recorded that the reduction in water yield due to forestation was approximately $50 \%$ (or $50 \mathrm{~mm}$ ) each year [8]. Wang et al. (2011) used published literature data in the past 50 years to show that the regional average of annual runoff for forestlands is only $16 \mathrm{~mm}-58 \%$ lower than that of 39 $\mathrm{mm}$ for non-forestlands [11].

Why are there different reductions of forests on water yield? Liu et al. (2015) discussed the effects of climate and forest change on streamflow in the upper reaches of Poyang River basin [12]. Sun et al. (2006) suggested that the large spatial and temporal variability of hydrologic responses to reforestation will follow gradients in climate, topography, soil, and disturbances in China [4]. There is no doubt that these previous conclusions can help us better understand the effects of forest on water yield. But researchers may have overlooked another factor. We doubt that, in different forest coverage, the strength or magnitude of the effects is the same.

So the key purpose of this study was to discuss the effects of forests on water yield in different forest cover percentages.

Northern China has a developed economy and serried cities, and is an important region for Chinese economic development. The rocky mountain area in northern China even serves as a water source for Beijing and many other cities. Unlike other areas (e.g., the Loess Plateau) [13-14], for this region there's enough water yield to ensure that domestic and industrial water is the most important environmental policy. Researching the forestwater relationship in this region has important practical significance.

\section{Material and Methods}

\section{Study Area}

The study area is the rocky mountain area of northern China (bounded by $35^{\circ} 4^{\prime}-44^{\circ} 11^{\prime} \mathrm{N}$ and $111^{\circ} 41^{\prime}-120^{\circ} 17^{\prime} \mathrm{E}$; Fig. 1). The total area is $264,832.7 \mathrm{~km}^{2}$ and accounts for $2.7 \%$ of the entire land area of China. The topography of the region is characterized by low-mountain and hilly landscapes. The elevation varies from 1 to $2,940 \mathrm{~m}$ above sea level. The soil texture is dominated by cinnamon soil. Different from other regions, the soil layer is very thin $(<1 \mathrm{~m})$, and forest coverage is low, about $20-30 \%$, with the main variety being broadleaved deciduous forest.

This study region has a semi-humid continental monsoon climate with a mean annual temperature of $12^{\circ} \mathrm{C}$. Rainfall in this study area is highly variable, both spatially and temporally. The mean annual rainfall generally ranges $350-800 \mathrm{~mm}$. More than $85 \%$ of the rain falls between June and October.

Before choosing the study watersheds, the catchment area is also a factor worth considering [8]. Oudin et al. (2008) found that the addition of land cover information

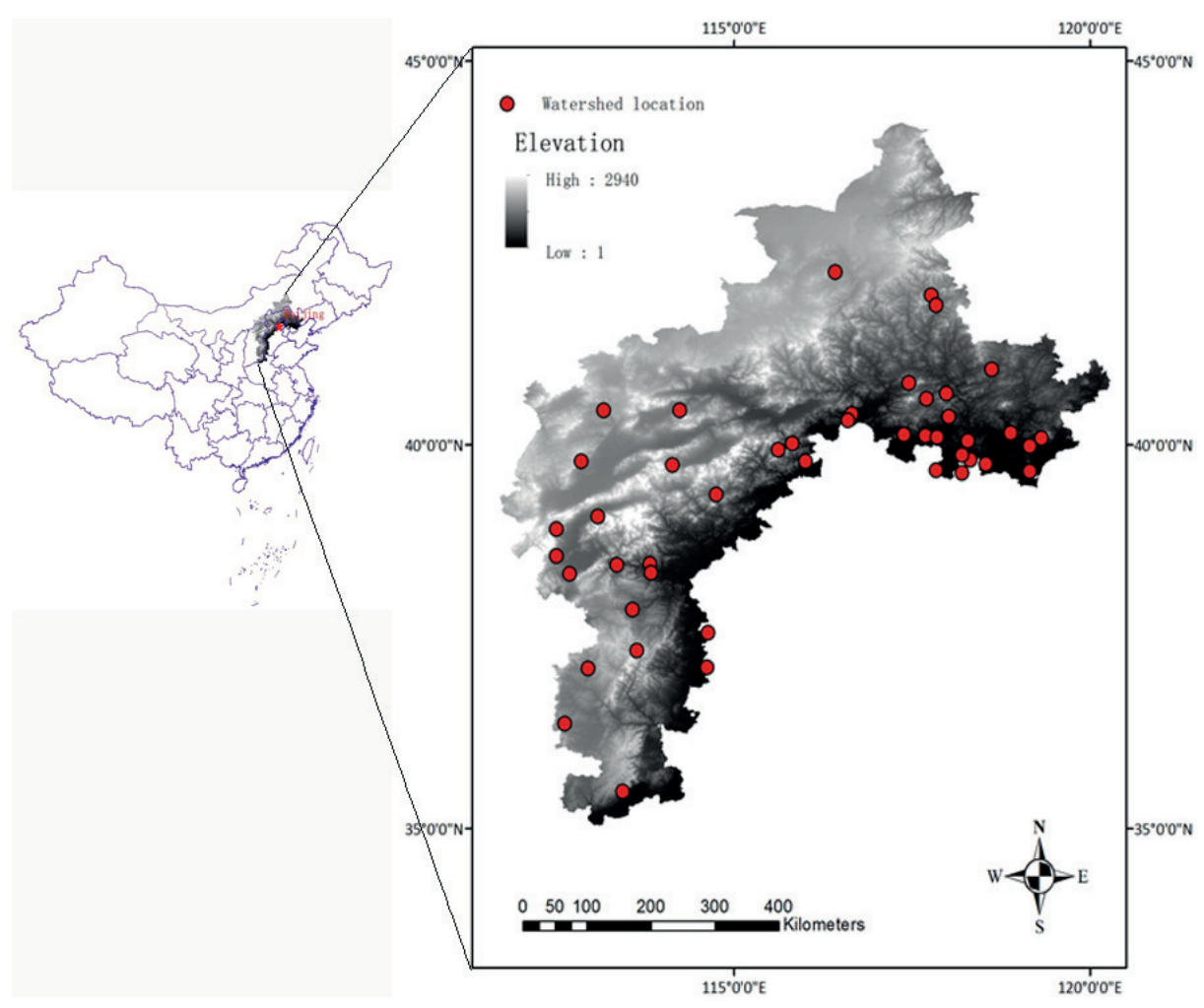

Fig. 1. Locations of study basins and distribution of elevation. 
did contribute to improving the efficiency of simple water balance formulas, particularly for catchment areas less than $1,000 \mathrm{~km}^{2}$ [15]. Donohue et al. (2007) noted that at large spatial scales $\left(>1000 \mathrm{~km}^{2}\right)$ climatic variables, rather than vegetation, primarily affect the long-term catchment water balance [16]. This indicates that 1,000 $\mathrm{km}^{2}$ may be the threshold to analyzing the forest impact on water yield. Therefore, in this study we only selected the watersheds of $<1,000 \mathrm{~km}^{2}$. For sufficient data sets, we then selected from them with a data period of $>10$ years. To exclude the interference of human factors on runoff, we also necessarily ensure that there are no water conservancy projects within the watersheds. Ultimately, we had selected the 42 eligible watersheds. Their locations are shown in Fig. 1.

\section{Data}

All the annual precipitation and runoff data (Table 1) were obtained from the Hydrological Yearbook of PR China (although the data have not been published, it is printed and issued for internal use). In order to ensure the quality of data sets, we also make reference to the relevant data from the China Meteorological Data Sharing Service System (www.cma.gov.cn).The digital elevation model (DEM) of this region was used to delineate the catchment boundaries of all catchments, and has a resolution of $90 \times 90 \mathrm{~m}$. The DEM and forest cover data are both derived from Data Sharing Infrastructure of Earth System Science (geodata.cn). And some forest cover data were also measure by Tracing Radiation and Architecture of Canopies (TRAC) from LICA United Technology Limited (www.li-ca.com).

\section{Methods}

Many factors could affect water yield, including climate, topography, soil, and vegetation. The classic paired catchment studies have been widely used as a means of determining changes in water yield resulting from forest change and excluding the effects of other environmental variables [17]. Unfortunately, very few normal paired catchment studies have been undertaken in China [11]. Consequently, we have to introduce an alternative approach to evaluate the hydrological impact of a forest. For example, Caballero et al. (2013) used the water balance model to analyze the impact of forest on mean annual runoff (MAR), based on the existing data sets of MAR and forest coverage [18]. Learning from their research, we also used this approach in our study.

Water balance is the most basic and important concept of watershed hydrology, and is a common framework for studying hydrological behaviors. It can be expressed as:

$$
P=E T+R+D+\Delta S
$$

...where $P$ is mean annual precipitation (MAP) (mm), ET is the mean annual evapotranspiration of a basin ( $\mathrm{mm}$ ), $R$ is mean annual runoff (MAR) (mm), $D$ is groundwater recharge, and $\Delta S$ is soil moisture changes. When the time series is long enough ( $>10$ years), $D$ and $\Delta S$ can be considered 0 . Then the water balance formula will be simplified as:

$$
P=E T+R
$$

...which guides us in analyzing runoff from precipitation and evapotranspiration.

\section{Results and Discussion}

\section{The Effect of Precipitation on Runoff and Evapotranspiration}

Precipitation is the source of runoff and evapotranspiration, and is the most important influencing factor. Before studying other environmental factors, the effect of precipitation should be well known.

All basins are selected to show the relationship among mean annual precipitation (MAP), mean annual evapotranspiration (MAET), and mean annual runoff (MAR) (Figs 2-3). The results show that there is a linear
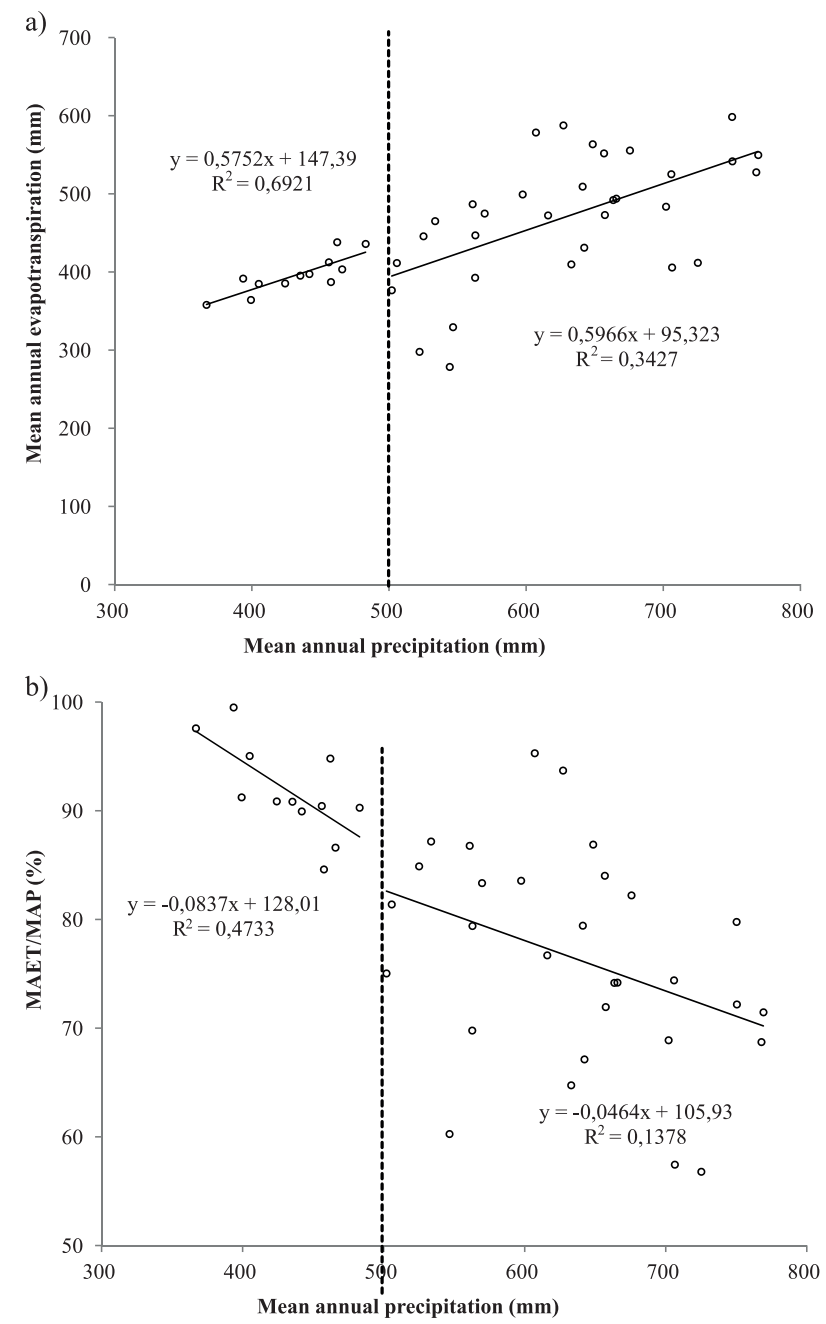

Fig. 2. Linear relationship between the a) MAET and b) MAP. 

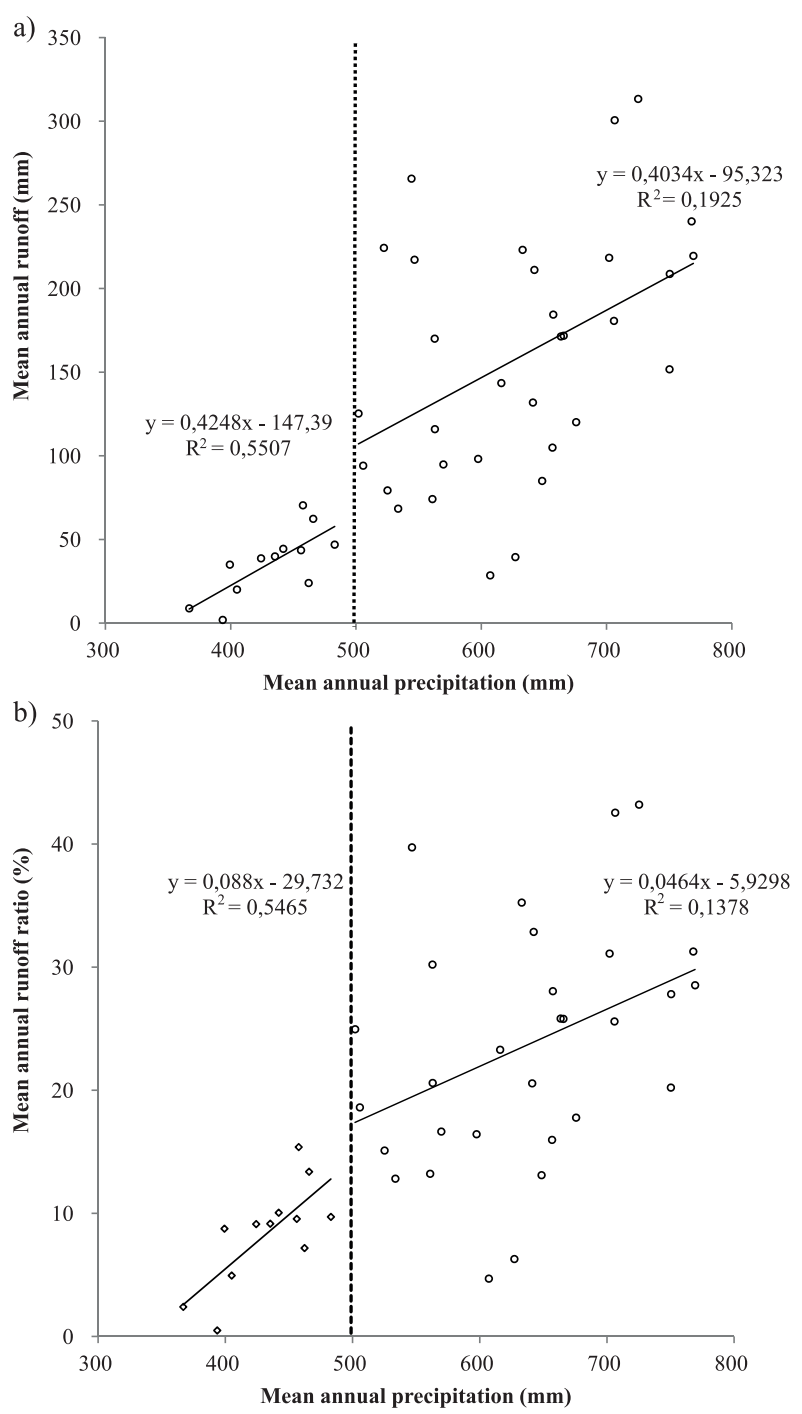

Fig. 3. Linear relationship between a) MAR and b) MAP.

relationship between MAP and MAET, but absolute $\operatorname{MAET}(\mathrm{mm})$ and proportional MAET (\% of precipitation) have different changes with increasing precipitation, and absolute MAET is also increasing while proportional MAET decreases. This means that when MAP is increasing, the part of the precipitation used as MAET is reduced. The relationship between MAP and MAR shows that they have a positive linear correlation and that both absolute MAR ( $\mathrm{mm}$ ) and proportional MAR (\% of precipitation) are increasing with increasing precipitation.

There should be good linear relationships among MAP, MAET, and MAR, but due to many environmental factors that commonly affect them, the relationships can be confusing. Our results indicate that the quality of relationships is different with different gradients of $\mathrm{P}$, and the data sets could be apparently divided into two parts. When MAP $<500 \mathrm{~mm}$, the linear relationships are slightly $\operatorname{good}\left(\mathrm{R}^{2}=0.6921,0.4733,0.5507,0.5465\right)$, while when MAP $>500 \mathrm{~mm}$, it becomes much weaker $\left(\mathrm{R}^{2}=0.3427\right.$, $0.1378,0.1925,0.1378)$. This may indicate that, with different precipitation, the effects of environment factors are also different.
An analysis in sub-regions or basin groups with different MAPs may be helpful in further improving our understanding as to how forestation may affect annual water yield [11]. In order to weaken the influence of rainfall, we try to divide the study basins into different groups according to their precipitation. So we use the MAP of $500 \mathrm{~mm}$ as the threshold for dividing the basins into two separate groups in the following analysis: the less-precipitation basin group and the more-precipitation basin group as associated with the climatic precipitation gradient.

The key to predicting and understanding the forest impact is to know which water balance component is the "winner" in affecting runoff [11]. As we all know, with increasing coverage, forest transpiration can decrease runoff. Although transpiration is traditionally considered the more important component of forest evapotranspiration (ET), interception and subsequent evaporation from the canopy can also increase substantially, particularly with conifers [19-20]. In general, forestation practices have caused decreases in annual runoff due to increases in evapotranspiration [21-22]. But on the other hand, the shade and litter of forest can reduce soil evaporation; forest roots can also enhance soil infiltration, which leads to greater percolation to groundwater and thus later could contribute toward low-flow discharges, which will both increase runoff. Then the final impact of forest on runoff depends on the synthetic effect of these positively and negatively influencing processes [10].

\section{The Impact of Forest on Runoff in the Less-Precipitated Basins}

When MAP is $<500 \mathrm{~mm}$, most of the basins have low forest coverage $(f)(0 \sim 30 \%)$, only two basins' forest coverage is much higher (about $72 \%$ ). By comparing these two basin groups ( $\mathrm{f}$ is $0 \sim 30 \%$ and $\mathrm{f}$ is about $72 \%$ ), we try to discuss the effects of forest on runoff. All information of the basins is shown in Table 2 .

Results show that the MAPs of these two basin groups have a small difference $(427.41 \mathrm{~mm}$ and $443.18 \mathrm{~mm}$, respectively). In this premise, though their forest coverage is much different, the MARs of this two basin groups are very similar for both the absolute MAR $(33.68 \mathrm{~mm}$ and $31.38 \mathrm{~mm}$ ) and the MAR ratio $(7.61 \%$ and $8.16 \%)$. In other words, though the forest coverage has a big increase (from $0 \sim 30 \%$ to $72 \%$ ), the change of MAR is very little. This may suggest that, when precipitation is low (MAP $<500$ $\mathrm{mm}$ ), the effects of forest on runoff are quite weak.

In this paper, the effect of forest on MAR is weak when precipitation is less than $500 \mathrm{~mm}$, and MAR shows a weak change with forest coverage increasing from $0 \sim 30 \%$ to about $72 \%$ - no matter the absolute value $(\mathrm{mm})$ or proportional value $(\%)$. This may because when precipitation is little, the effect of forest on evapotranspiration is also limited. Notably, ET is usually accounting for $>90 \%$ of precipitation in dryland ecosystems [23]. Travis E. Huxman et al. (2005) believe that forests influence ET to a greater extent in more 
Table 1. Collected data sets from selected watersheds.

\begin{tabular}{|c|c|c|c|c|c|}
\hline ID & Watershed & Area $\left(\mathrm{km}^{2}\right)$ & Forest coverage $(\%)$ & MAP (mm) & $\operatorname{MAR}(\mathrm{mm})$ \\
\hline 1 & Daqinggou & 366 & 13.9 & 366.86 & 8.85 \\
\hline 2 & Dahekou & 999 & 0.5 & 390.51 & 71.14 \\
\hline 3 & Nantuling & 575 & 15.7 & 393.58 & 1.94 \\
\hline 4 & Fengzhen & 1000 & 2.5 & 399.28 & 34.98 \\
\hline 5 & Wujiayao & 138 & 4.0 & 404.95 & 20.08 \\
\hline 6 & Qingbaikou & 550 & 72.1 & 424.19 & 38.75 \\
\hline 7 & Weichang & 997 & 27.9 & 435.27 & 39.90 \\
\hline 8 & Bianqiangshan & 562 & 20.2 & 441.91 & 44.44 \\
\hline 9 & Douluoqiao & 712 & 6.4 & 456.09 & 43.60 \\
\hline 10 & Luzhuang & 746 & 16.1 & 457.62 & 70.44 \\
\hline 11 & Qingshui & 301 & 72.7 & 462.17 & 24.00 \\
\hline 12 & Wangjiahui & 396 & 16.5 & 465.81 & 62.37 \\
\hline 13 & Huili & 475 & 15.0 & 482.93 & 46.94 \\
\hline 14 & Siping & 192 & 16.9 & 501.98 & 125.30 \\
\hline 15 & Macun & 973 & 0.4 & 505.69 & 94.13 \\
\hline 16 & Baiyachang & 92 & 61.4 & 522.23 & 224.31 \\
\hline 17 & Yangquan & 584 & 5.7 & 525.11 & 79.35 \\
\hline 18 & Pingquan & 372 & 2.2 & 533.60 & 68.43 \\
\hline 19 & Shimen & 502 & 6.4 & 544.25 & 265.67 \\
\hline 20 & Longmenkou & 126 & 53.5 & 546.66 & 217.22 \\
\hline 21 & Liujiaping & 140 & 6.2 & 562.76 & 170.04 \\
\hline 22 & Beizhangdian & 264 & 31.4 & 562.92 & 115.95 \\
\hline 23 & Shizhandao & 830 & 13.0 & 569.71 & 94.86 \\
\hline 24 & Wangan & 416 & 13.5 & 597.44 & 98.18 \\
\hline 25 & Hancun & 379 & 0.0 & 607.09 & 28.56 \\
\hline 26 & Tangshan & 668 & 6.6 & 615.96 & 143.49 \\
\hline 27 & Zhaojiagang & 44 & 0.3 & 627.15 & 39.49 \\
\hline 28 & Liying & 568 & 20.9 & 632.92 & 223.12 \\
\hline 29 & Zhenzizhen & 128 & 8.9 & 641.16 & 131.87 \\
\hline 30 & Qianmaozhuang & 340 & 40.0 & 642.32 & 211.13 \\
\hline 31 & Manshuihe & 640 & 45.8 & 648.52 & 85.01 \\
\hline 32 & Shifokou & 429 & 16.7 & 656.77 & 104.92 \\
\hline 33 & Yangjiaying & 143 & 7.3 & 657.40 & 184.43 \\
\hline 34 & Lijiaxuan & 902 & 10.9 & 663.51 & 171.38 \\
\hline 35 & Fuguizhuang & 263 & 11.6 & 665.72 & 171.79 \\
\hline 36 & Yuhekou & 528 & 86.0 & 675.67 & 120.14 \\
\hline 37 & Koutou & 170 & 37.6 & 701.99 & 218.38 \\
\hline 38 & Yumenkou & 157 & 59.4 & 706.41 & 300.60 \\
\hline 39 & Nihe & 478 & 20.0 & 750.18 & 151.72 \\
\hline 40 & Shuipingkou & 742 & 21.5 & 750.39 & 208.72 \\
\hline 41 & Lanqiying & 714 & 46.0 & 767.80 & 240.14 \\
\hline 42 & Luozhuangzi & 322 & 66.8 & 769.23 & 219.51 \\
\hline
\end{tabular}


Table 2. Collected data sets of MAP, MAR, and forest coverage $(f)$ from the less-precipitated basins.

\begin{tabular}{|c|c|c|c|c|c|}
\hline & Name & $f$ & $\operatorname{MAP}(\mathrm{mm})$ & MAR (mm) & MAR ratio (\%) \\
\hline \multirow{10}{*}{$\begin{array}{c}f \text { is } \\
0 \%-30 \%\end{array}$} & Fengzhen & $2.46 \%$ & 399.28 & 34.98 & $8.76 \%$ \\
\hline & Wujiayao & $3.98 \%$ & 404.95 & 20.08 & $4.96 \%$ \\
\hline & Douluoqiao & $6.42 \%$ & 456.09 & 43.60 & $9.56 \%$ \\
\hline & Daqinggou & $13.92 \%$ & 366.86 & 8.85 & $2.41 \%$ \\
\hline & Huili & $14.97 \%$ & 482.93 & 46.94 & $9.72 \%$ \\
\hline & Nantuling & $15.70 \%$ & 393.58 & 1.94 & $0.49 \%$ \\
\hline & Wangjiahui & $16.47 \%$ & 465.81 & 62.37 & $13.39 \%$ \\
\hline & Bianqiangshan & $20.22 \%$ & 441.91 & 44.44 & $10.06 \%$ \\
\hline & Weichang & $27.89 \%$ & 435.27 & 39.90 & $9.17 \%$ \\
\hline & \multicolumn{2}{|c|}{ Mean value } & 427.41 & 33.68 & $7.61 \%$ \\
\hline \multirow{3}{*}{$\begin{array}{c}f \text { is } \\
\text { about } 72 \%\end{array}$} & Qingbaikou & $72.06 \%$ & 424.19 & 38.75 & $9.14 \%$ \\
\hline & Qingshui & $72.73 \%$ & 462.17 & 24.00 & $7.19 \%$ \\
\hline & \multicolumn{2}{|c|}{ Mean value } & 443.18 & 31.38 & $8.16 \%$ \\
\hline
\end{tabular}

mesic climates and less so in arid climates [24]. Bari et al. (2015) also said that, in arid environments (those in which potential evapotranspiration is many times greater than precipitation), woody plants have comparatively little effect on the water budget - for the simple reason that most of the water in these landscapes is evaporated regardless of vegetation cover [23]. Even though northern China is a semiarid landscape (not an arid environment), its potential evapotranspiration in less-precipitated areas is also much greater than precipitation, and most of the water is also evaporated, ET accounts for $85 \sim 100 \%$ (Fig. 2). Therefore, the forest had a little effect on runoff in the less-precipitated area $(<500 \mathrm{~mm})$.

\section{The Impact of Forest on Runoff in the More-Precipitated Basins}

When MAP is $>500 \mathrm{~mm}$, the effects of forest on runoff is much more complex than the less-precipitated area. We examined the forest's effects by the changes of runoff with increasing forest coverage (Fig. 4). The MAP of the basins has a large range of variation; to weaken the influence of rainfall, more than the absolute MAR, we also selected the MAR ratio (percentage of precipitation) as another indicator.

Both the absolute MAR and the MAR ratio have the same change trend with increasing forest coverage, and the change trend of MAR is respectively increasing, stable, and decreasing. This may suggest that, when $f$ is small, the effect of forest is increasing runoff; when $f$ is big, the effect is much weaker; and when $f$ is much bigger, forest decreases runoff. In addition, the largest absolute MAR is about $225 \mathrm{~mm}$ and the largest MAR ratio is about $35 \%$.

When precipitation is more ( $>500 \mathrm{~mm}$ in this paper), the effect of forest on MAR is much more complex.
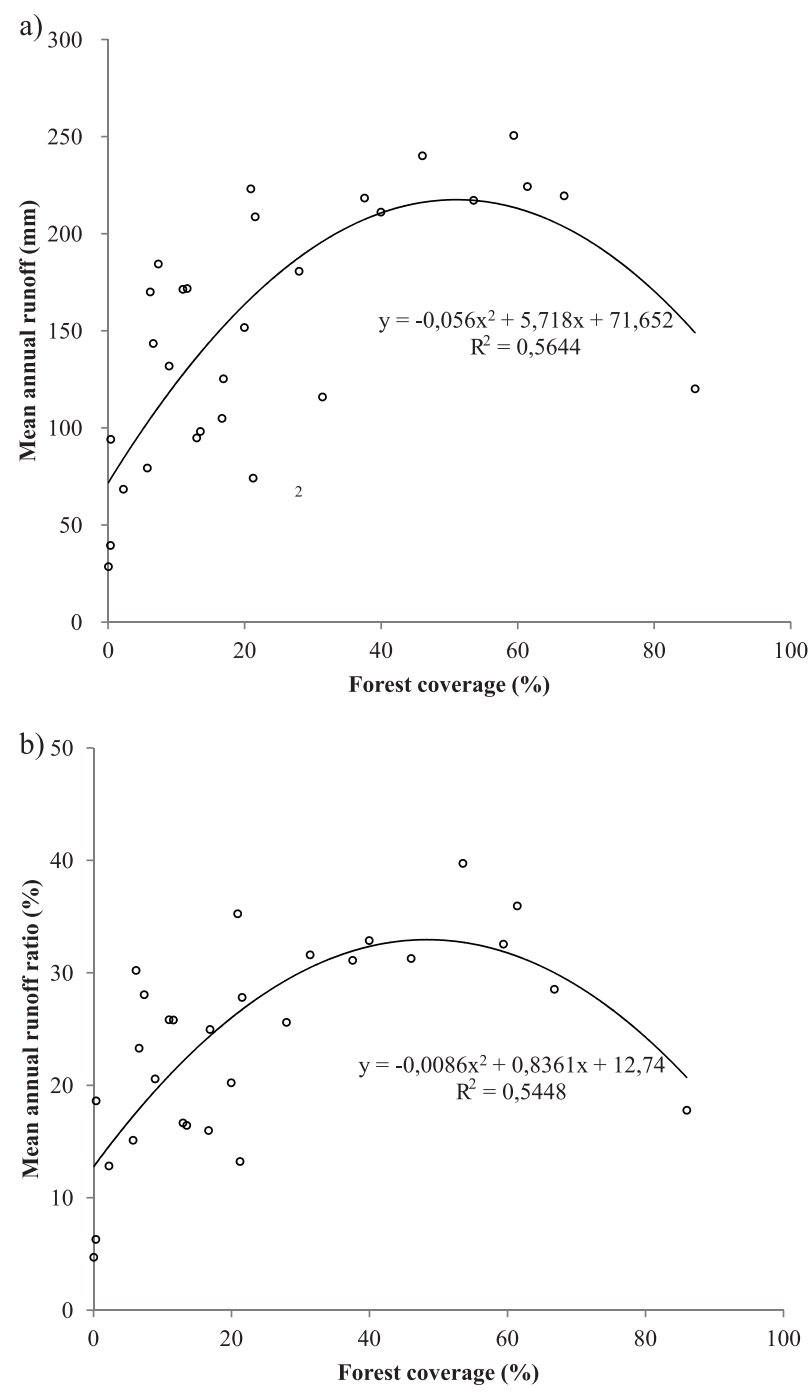

Fig. 4. Changing trends in MAR with forest coverage for the more-precipitated basins (MAP $>500 \mathrm{~mm}$ ). 
Our results showed that with increasing forest coverage the MAR had a trend of "increasing-stable-decreasing." Wang et al. noted that the key to predicting and understanding the forest impact is to know which water balance component is the winner in affecting runoff [11, 25-28]. This trend may reflect different winners in different stages of the fight between the negative and positive effects of forest on runoff [29-31]. When forest coverage is low $(<20 \%)$, soil evaporation rather than tree transpiration is the main part of basin evapotranspiration, and then the positive effects of reducing soil evaporation and enhancing soil infiltration may be the winner. When forest coverage is much higher $(>60 \%)$, increasing trees transpiration becomes a major component and, taking the increasing canopy interception into account, the negative effects become the winner while the positive effects are much more limited.

The effects of forest on runoff in greater-precipitation areas $(>500 \mathrm{~mm})$ show that, initially, the positive effects may be a major component, and with increasing forest coverage the negative effects are also increasing and gradually win. So we guess there may be a point or period where the negative and positive effects are evenly matched, and has the largest runoff.

\section{Conclusions}

Using statistical and graphical analyses on the long-term hydrological data of the 42 watersheds in northern China, we were able to analyze the impact trend of forest on runoff. We conclude that the impact of forest on runoff is very weak in the less-precipitated regions (in this study $<500 \mathrm{~mm}$ ). And in the more-precipitated regions $(>500 \mathrm{~mm})$ the effects of forest on runoff are much more complex, and cannot simply be stated as increases or decreases. With increasing forest coverage $(f)$, runoff shows a trend of "increasing-stabledecreasing," and the largest absolute MAR in northern China is about $225 \mathrm{~mm}$ and the largest MAR ratio is about $35 \%$. Those results have some implications for reforestation programs, and are just a first step toward better understanding the forest-water relationship.

It is important to highlight that there remains a lot of uncertainty in this statistical analysis of forest impact on runoff. In addition to precipitation and forests, other meteorological factors (e.g., temperature) and terrain factors (e.g., slope) also could affect runoff. This study area is located in the same climatic zone and mostly is the rocky mountain area, and its meteorological and topographical factors have little change, but after all cause a deviation of our research results. Due to the lack of paired catchments, it is difficult to remove these additional factors. On the other hand, in order to ensure sufficient data sets we select the only 42 watersheds in which the data period is more than 10 years old and may not be sufficient to represent the entire study area. We should try to remove these deficiencies from future research.

\section{Acknowledgements}

This research was financially supported by the Central Nonprofit Research Institution's Basic Scientific Research Special Fund (CAFYBB2016SY032).

\section{References}

1. YAO Y.F., CAI T.J., WEI X.H., ZHANG M.F., JU C.Y. Effect of forest recovery on summer streamflow in small forested watersheds, Northeastern China. Hydrological Processes. 26, 1208, 2011.

2. ZHANG M., WEI X. The effects of cumulative forest disturbance on streamflow in a large watershed in the central interior of British Columbia, Canada. Hydrology \& Earth System Sciences. 16, 2021, 2012.

3. ZHANG M., WEI X. The cumulative effects of forest disturbance on streamflow in a large watershed in the central interior of British Columbia, Canada. Hydrology \& Earth System Sciences Discussions. 9, 2855, 2012.

4. SUN G., ZHOU G., ZHANG Z., WEI X., MCNULTY S.G., VOSE J.M. Potential water yield reduction due to forestation across China. Journal of Hydrology. 328, 548, 2006.

5. BATELIS S.C., NALBANTIS I. Potential Effects of Forest Fires on Streamflow in the Enipeas River Basin, Thessaly, Greece. Environmental Processes. 1, 73, 2014.

6. LOPES V.L., FFOLLIOTT P.F. Effects of Forest Harvesting Practices on Streamflow-Sediment Relationships for Southwestern Ponderosa Pine Watersheds// Watershed Management Planning for the 21st Century. ASCE, 2014.

7. FARLEY K.A., JOBBAGY E.G., JACKSON R.B. Effects of afforestation on water yield: a global synthesis with implications for policy. Global Change Biology. 11, 1565, 2005.

8. PEEL M.C., MCMAHON T.A., FINLAYSON B.L. Vegetation impact on mean annual evapotranspiration at a global catchment scale. Water Resources Research. 46, W09508, 2010.

9. BECK H.E., BRUIJNZEEL L.A., DIJK AIJMV., MCVICAR T.R. The impact of forest regeneration on streamflow in 12 meso-scale humid tropical catchments. Hydrology \& Earth System Sciences Discussions. 17, 2613, 2013.

10. YAO Y., CAI T., WEI X., ZHANG M., JU C. Effect of forest recovery on summer streamflow in small forested watersheds, Northeastern China. Hydrological Processes. 26, 1208, 2012.

11. WANG Y.H., YU P.T., KARL-HEINZ FEGER, WEI X.H., SUN G., MIKE BONELL, XIONG W., ZHANG S.L., XU L.H. Annual runoff and evapotranspiration of forestlands and non-forestlands in selected basins of the Loess Plateau of China. Ecohydrology. 4, 277, 2011.

12. LIU W., WEI X., LIU S., LIU Y., FAN H., ZHANG M., YIN J., ZHANG M. How do climate and forest changes affect long-term streamflow dynamics? A case study in the upper reach of Poyang River basin. Ecohydrology. 8, 46, 2015.

13. ZHANG L., KARTHIKEYAN R., BAI Z., SRINIVASAN R. Analysis of streamflow responses to climate variability and land use change in the Loess Plateau region of China. Catena. 154, 1, 2017.

14. JIAN S., ZHAO C., FANG S., YU K. Effects of different vegetation restoration on soil water storage and water 
balance in the Chinese Loess Plateau. Agricultural \& Forest Meteorology. 206, 85, 2015.

15. OUDIN L., ANDREASSIAN V., LERAT J., MICHEL C. Has land cover a significant impact on mean annual streamflow? An international assessment using 1508 catchments. Journal of Hydrology. 357, 303, 2008.

16. DONOHUE R.J., RODERICK M.L., MCVICAR T.R. On the importance of including vegetation dynamics in Budyko's hydrological model. Hydrology and Earth System Sciences. 11, 983, 2007.

17. BREN L. Impacts of Native Forest Management on Catchment Hydrology [M]// Forest Hydrology and Catchment Management. Springer Netherlands, 2015.

18. CABALLERO L.A., EASTON Z.M., RICHARDS B.K., STEENHUIS T.S. Evaluating the bio-hydrological impact of a cloud forest in Central America using a semidistributed water balance model. Journal of Hydrology \& Hydromechanics. 61, 9, 2013.

19. BART R.R., TAGUE C.L., MORITZ M.A. Effect of Treeto-Shrub Type Conversion in Lower Montane Forests of the Sierra Nevada (USA) on Streamflow. Plos One. 11, e0161805, 2016.

20. PERRY T.D., JONES J.A. Summer streamflow deficits from regenerating Douglas-fir forest in the Pacific Northwest, USA. Ecohydrology, 2016.

21. KABEYA N., CHAPPELL N.A., TYCH W., SHIMIZU A., ASANO S., HAGINO H. Quantification of the effect of forest harvesting versus climate on streamflow cycles and trends in an evergreen broadleaf catchment. Hydrological Sciences Journal/journal Des Sciences Hydrologiques. 61, $150311053604008,2015$.

22. WEI X.H., SUN G., LIU S.R., JIANG H., ZHOU G.Y., DAI L.M. The forest-streamflow relationship in China: A 40year retrospect. Journal of the American Water Resources Association. 44, 1076, 2008.

23. BARI M.A., SMITH N., RUPRECHT J.K., BOYD B.W. Changes in streamflow components following logging and regeneration in the southern forest of Western Australia. Hydrological Processes. 10, 447, 2015.
24. TRAVIS E. HUXMAN, BRADFORD P. WILCOX, DAVID D. BRESHEARS, RUSSELL L. SCOTT, KEIRITH A. SNYDER, ERIC E. SMALL, KEVIN HULTINE, WILLIAM T. POCKMAN, ROBERT B. JACKSON. Ecohydrological Implications of woody plant encroachment. Ecology. 86, 308, 2005.

25. DIAS L.C.P., MACEDO M.N., COSTA M.H., COE M.T., NEILL C. Effects of land cover change on evapotranspiration and streamflow of small catchments in the Upper Xingu River Basin, Central Brazil. Journal of Hydrology Regional Studies. 4, 108, 2015.

26. KIM, JINSOO, PARK, SOYOUNG. Potential Effects of Urban Growth under Urban Containment Policy on Streamflow in the Gyungan River Watershed, Korea. Journal of the Korean Society of Surveying Geodesy Photogrammetry \& Cartography. 33, 163, 2015.

27. MURRAY C. PEEL, THOMAS A. MCMAHON, BRIAN L. FINLAYSON. Vegetation impact on mean annual evapotranspiration at a global catchment scale. Water Resources Research. 46, W09508, 2010.

28. KELLY C.N., MCGUIRE K.J., MINIAT C.F., VOSE J.M. Forest management changes streamflow response to increasing precipitation extremes. Geophysical Research Letters, 2016.

29. TAKAGI M. Water chemistry of headwater streams under stormflow conditions in catchments covered by evergreen broadleaved forest and by coniferous plantation. Landscape and Ecological Engineering. 11, 293, 2015.

30. WANG Y.H., YU P.T., XIONG W., SHEN Z.X., GUO M.C., SHI Z.J., DU A.P., WANG L.M. Water yield reduction after afforestation and related processes in the semiarid Liupan Mountains, Northwest China. Journal of the American Water Resources Association. 44, 1086, 2008.

31. YU P.T., KRYSANOVA V., WANG Y.H., XIONG W., MO F., SHI Z.J., LIU H.L., VETTER T., HUANG S.C. Quantitative estimate of water yield reduction caused by forestation in a water-limited area in Northwest China. Geophysical Research Letters. 36, L02406, 2009. 